\title{
23 The reuse of Latin in the modern languages of science
}

\$1 It has been claimed that modern science contains more words derived from Greek than Ancient Greek had as a whole. ${ }^{1}$ Now, this is hardly a scientific statement: ${ }^{2}$ Ancient Greek could easily coin new words and no one knows how many were ever used. Indeed, the question of how many words a language possesses is seen as meaningless today. Nonetheless, the number of scientific English words today made up from Greek constituents is very large indeed. This chapter continues the previous chapter's approach to comparing what languages do with the Greek and Latin scientific word material, but this time the focus is on contemporary languages of science, which are all clearly dependent in their content on European science and thus Graeco-Latin science.

\$2 A sample of technical terms in two very different sciences ${ }^{3}$ in eight languages is considered here in order to see how languages solve the task of taking over modern Western European scientific content: on the one hand chemistry, in its current form a young science (Lavoisier discovered the periodic table in 1789) with many new concepts that came into being only after the hegemony of Latin was broken, on the other hand linguistics, which is based on ancient grammar theory and vocabulary, but also developed in strikingly novel ways in the eighteenth and nineteenth centuries. I picked a dozen terms from each of the sciences in question, quite at random but from different topics and taking care to cover different PoS, and then I checked how the languages in question express them. Even at a glance, it will become apparent that most of them are based on Greek or Latin: both these languages are still in high favour today among people inventing new scientific concepts (see chap. 21 above). The languages chosen were French, English, German, Icelandic, Russian, Modern Greek, Arabic, and Chinese. ${ }^{4}$ A first cri-

1 A version of this chapter was presented at the congress 'Deutsch als Wissenschaftssprache um 1800', Berlin, June 2016, organised by Claude Haas and Daniel Weidner.

2 The claim comes from Hitchings (2008: 182), quoted in Gordin (2015b: 299).

3 As Fleck already pointed out: 'Der Zusammenhang z. B. von Linguistik und Chemie ist tatsächlich geringfügig' ('The connection of, for instance, linguistics and chemistry is indeed slight'; 2011: 368).

4 For Icelandic, I used Icelandic Online Dictionary and Readings, Ritmálssafn Orðabókar Háskólans, Böðvarsson, and de Vries; for Russian Derksen and Vasmer; for Modern Greek Мл $\mu \mu \pi \mathrm{-}$

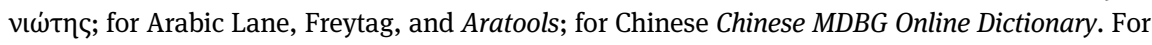
all languages, Wiktionary was also consulted.

Ә Open Access. ( 2021 Philipp Roelli, published by De Gruyter. (C)BY This work is licensed under the Creative Commons Attribution 4.0 International License.

https://doi.org/10.1515/9783110745832-024 
terion for inclusion was that a language should be internationally relevant in the sciences today, adding Icelandic, which is known for hardly ever admitting loanwords, as well as Modern Greek and Arabic as the direct descendants of once very important languages of science. French can stand for the Romance languages in general, which tend to be very similar in their scientific vocabulary, and Russian for the Slavonic ones. English, German, and Icelandic will show the diversity among the Germanic languages, which range from largely borrowing from Latin to nearly exclusively making their own calques. Chinese is included as an outlier, a culture that had its own kind of scholarship that hardly ever borrows directly and much of which depends on its complex and archaic writing system. Due to this, the Chinese characters are included as they have their own etymologies, the pronunciation often being polysemous.

Tables 30 and 31 provide the structure of the sampled words by adding morpheme-by-morpheme translations. The lists also contain a - mostly approximate date for each concept's first use. It would be very interesting to have access to such dates for all the languages in question, but most languages are not as well documented as English and have no equivalent of the $O E D$. The character 'o' indicates the language in which the concept was probably first used; italicised terms are based on Greek or Latin, other loanwords are formatted in bold, and calques are underlined - in other words, terms not specially formatted are 'native'. The last row attempts to summarise these pieces of information by giving figures for how often a concept originated in the column's language, how often it stemmed from the classical languages, how often there was a loanword, and how often a calque. This system is too primitive to account for all cases. For instance, how should a word be counted that is coined in German but from Greek constituents (such as Morphem)? The numbers should thus be taken only as a quick overview of the favoured types used in the different languages. In some cases, especially in linguistics, there is no available standard term in some of the languages; these cases are marked with '?'. Such cases were rather to be expected - as science is not as easily and automatically translatable, as has sometimes been claimed (chap. $16 \S 1$ ) - but they are quite rare.

\$3 A few more words on Chinese and its writing system may be helpful for readers not familiar with language and script. Basically, one character represents one concept, although today two near-synonyms have often coalesced into one 'word' as there are so many homophones (e.g. 啤酒 píjiǔ literally 'beer-liquor', but in fact the normal term for 'beer'). The characters were already standardised in Xǔ Shèn's (ca. AD 58-ca. 148) lexicon Shuō wén jiě zì, which contains some 9,500 characters and already uses a classification of simple characters, compound characters, and radicals (used to sort the characters). The basis of the modern standard lexicon is 
the Kāngxī zidiăn (from 1710) with some 47,000 characters ordered by 214 radicals. Character compounds can contain semantic and phonetic components (phonetic for Mandarin, that is). For example, the character 鈈 bù ('plutonium') is formed from 金 jīn ('metal') and 不 bù ('nothing'), which has the same pronunciation but whose meaning has nothing to do with 'plutonium'. In fact, this is a general characteristic of the Chinese script. For example, the character 语 yŭ ('language') consists of i ('speech' radical) + $\square$ kǒu ('mouth') + 五 wǔ ('five'); this last component is purely phonetic - it sounds similar to yŭ. ${ }^{5}$ Equipped with this writing system that contains much of Chinese culture and ideology, Chinese goes very much its own way when dealing with new concepts. It only reluctantly and still very rarely begins to adopt occasional loanwords in the twentieth century, ${ }^{6}$ for instance 代拿买特 dàinámăitè ('dynamite'). ${ }^{7}$ Within this writing system, such an approach is problematic, as each character not only has a pronunciation but also a meaning, in this case 'period', 'catch', 'buy', 'unique' - which has absolutely nothing to do with 'dynamite'. There is a state institution that takes care of standardising new scientific coinings in the People's Republic. ${ }^{8}$ With great effort, this system inherent in Chinese writing was put to use in expanding scientific terminology in Chinese and was successful in adopting the Western scientific $B e$ griffsgemeinschaft. In Chinese, new concepts are very often expressed by character compounds or by adding strokes to existing characters.

\$4 The sample words follow in tables 30 and 31.

5 More on Chinese writing and its history in Bottéro (2001).

6 One might think that their very different phonetics prevent the Chinese from loaning, but as Japanese (with a similar phonetic problem) shows, this is not the case: dainamaito ('dynamite'), gurukōsu ('glucose'), metafijikkusu ('metaphysics'), and many more examples, all written in syllabic katakana script, are normal Japanese today.

7 See Yeun-wen Pao (1983) and the wiki list https://en.wikipedia.org/wiki/List_of_loan words_in_Chinese. Today, there are other native terms for 'dynamite' in Chinese, such as 甘油炸药 gānyóu zhàyào, literally 'glycerine explosive'.

8 http://www.most.gov.cn/eng/. 

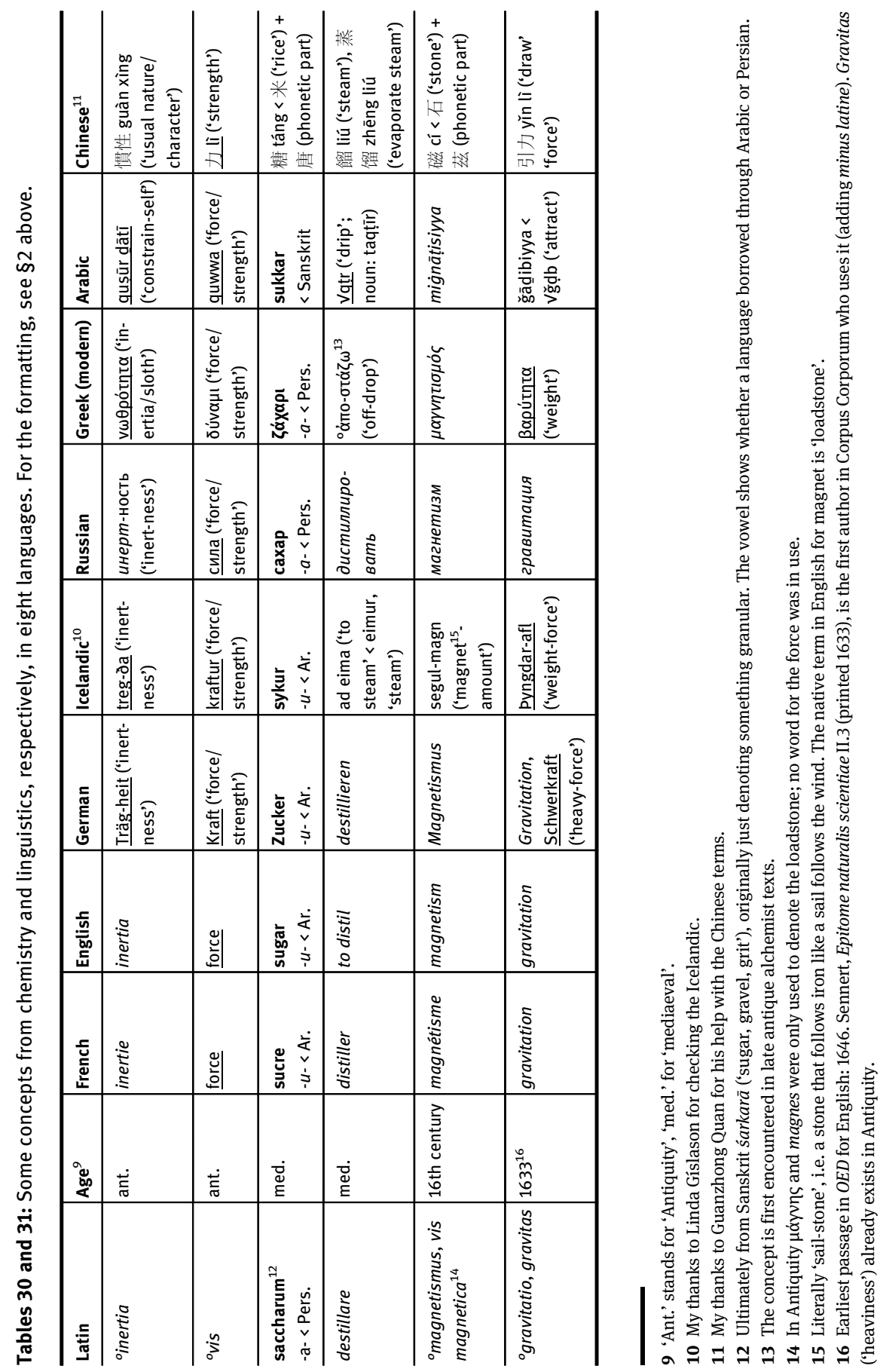


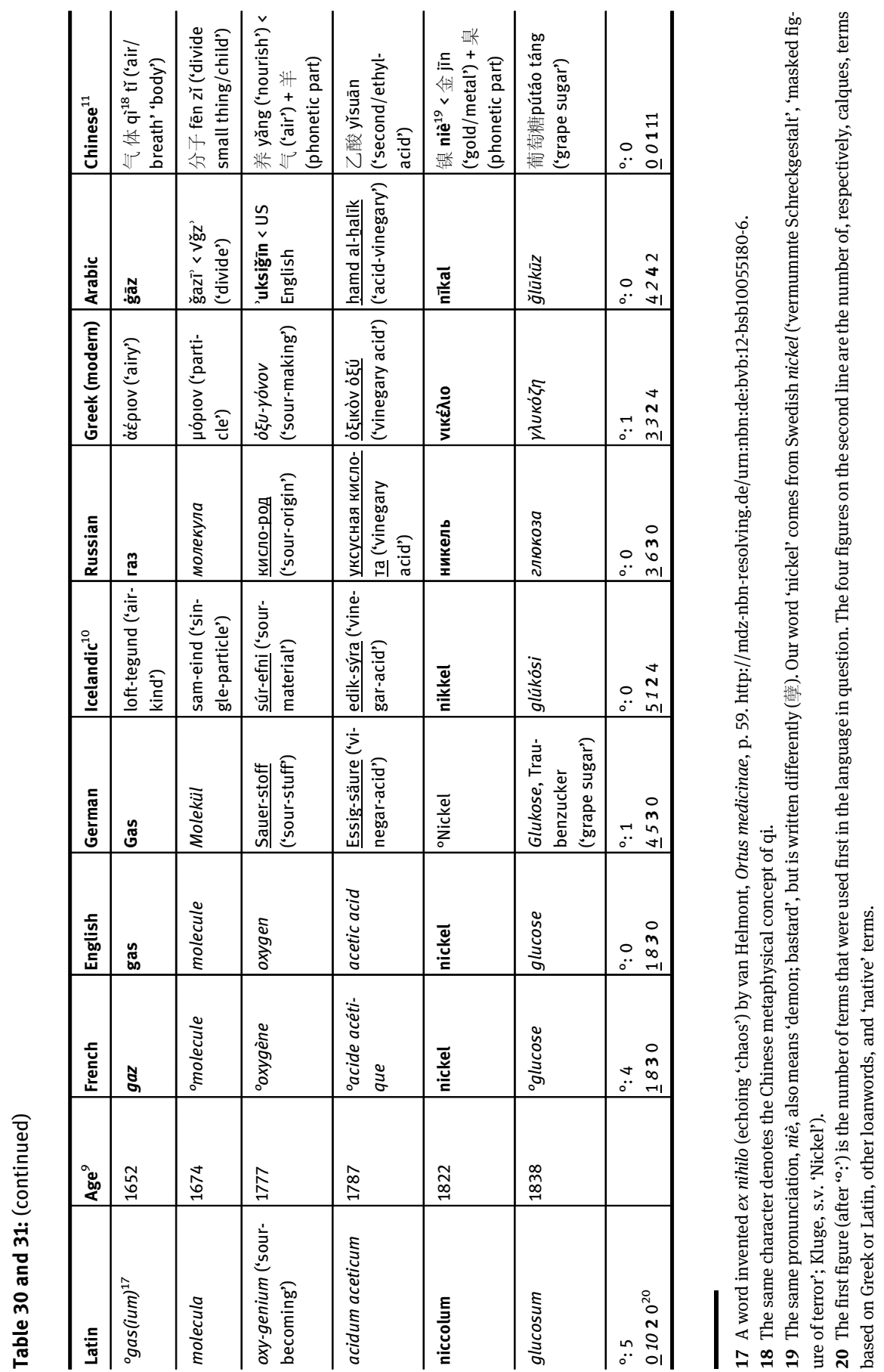



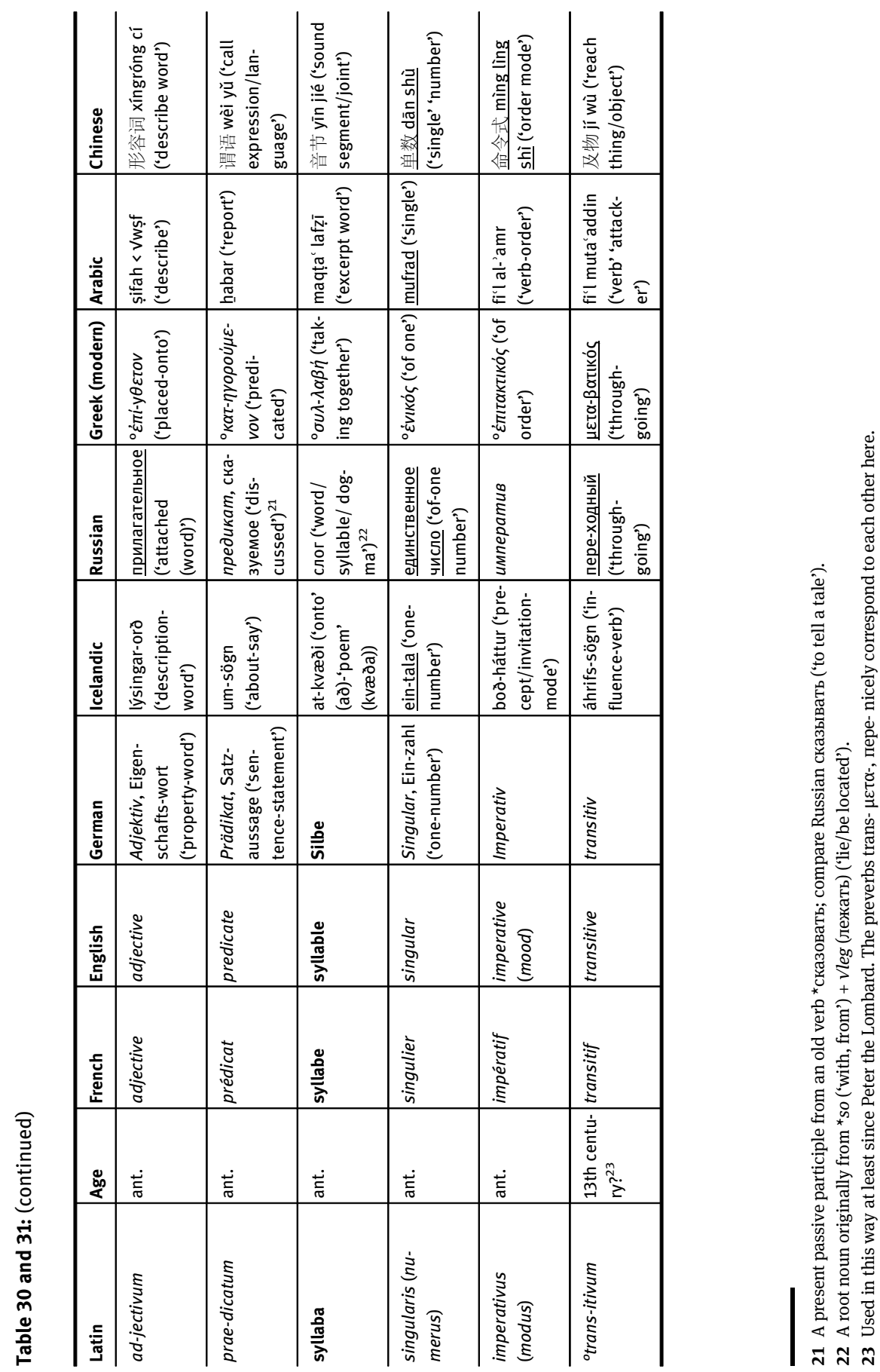


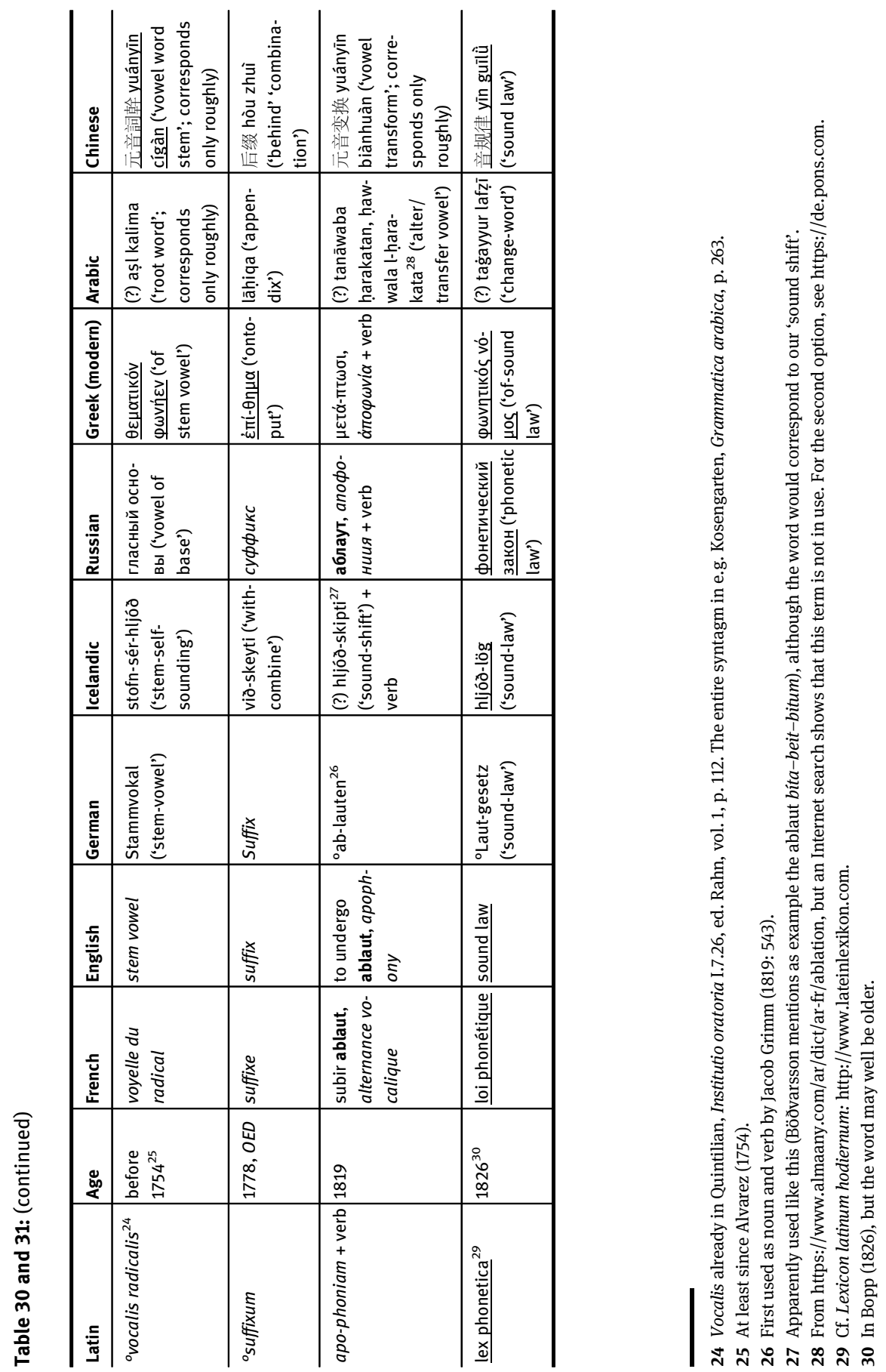




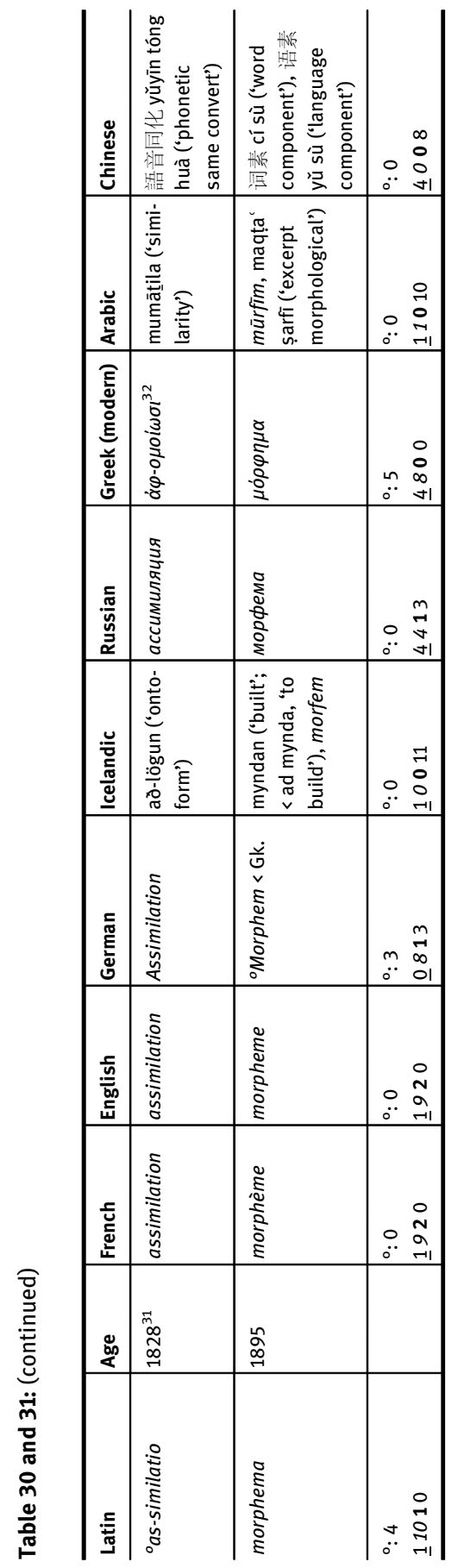

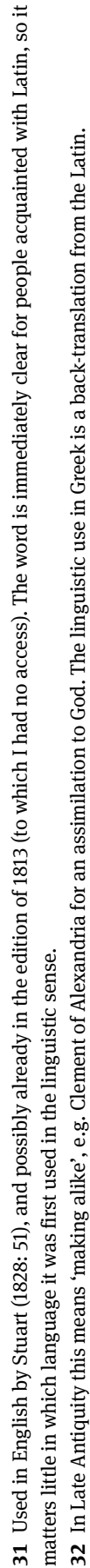


For some of the terms considered, more context is needed. The word for 'force' in physics was calqued from Greek into Latin, and from there to the other languages, all of them using calques and a word expressing physical 'strength'; 'force' is derived from the Late Latin abstract fortia, ${ }^{33}$ which in the vernacular languages replaced vis altogether. 'To distil' is a different case: although it was also calqued from Greek into Latin, most other European languages then just took over the Latin word as a loan. More recent coinings such as 'molecule' or 'morpheme' are even more often taken over as mere loanwords. For the formation of the words in the other languages, it mostly matters little whether a word was first used in Latin, French, or English, as in all these cases Latin constituents were normally used. On the whole, French, English, German, and Russian - all of which were important languages for scientific publications throughout the twentieth century - often use very similar terminology. Icelandic, Modern Greek, and often Arabic, all of which hardly fulfilled this function, disagree more often. In some cases, Arabic also uses loans (such as uksiǧin). In ordinary speech, Icelandic hardly ever admits loanwords, but in chemical nomenclature it cannot avoid some; compare sýker and glúkósi.

In the case of Russian, it must be remembered that it only became a language of scientific communication toward the end of the nineteenth century. Although it can form new compounds rather easily (кислород, переходный) it often uses loanwords. Modern Greek only very rarely adopts Latin words; whenever possible it takes a classical (or classical-sounding) equivalent for new Latin concepts (such

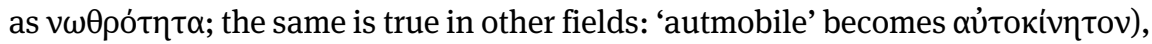
but new, well-formed Western coinings from Greek constituents are taken over readily (ółuyóvov). Loanwords seem to be more common in the natural science of chemistry than in the human science of linguistics. Among the linguistics examples, Chinese, Icelandic, and Modern Greek use no loanwords at all, Arabic only one (mūrfim). ${ }^{34}$

The more recent a scientific term is, the harder it may be to find a translation for it in languages that are not among the major scientific languages. Even the largest dictionaries in existence may not contain the words for 'to undergo ablaut' or 'acetic acid'. In linguistics, terms for phenomena that only exist in some language groups may not have a fixed name in languages that lack them: I found no certain corresponding Arabic terms for 'undergo ablaut', 'sound law', and 'stem vowel'. The Arabic language's translations amount to a description that

33 See Stotz (1996-2004: VIII, §12.7 = vol. 4, p. 39 with n480).

34 Compare the similar comparative list between many more terms of the natural sciences, but only from Germanic and Romance languages (English, German, Swedish, French, Spanish, and Italian) in Savory (1953: 160-162). 
sounds rather too general (e.g. tanāwaba harakatan, 'alter vowel'). Similarly, Chinese uses a cumbersome 元音变换 ('phonetic same convert') for our 'assimilation'. Thus, it becomes clear that even today not all sciences are equally international. For languages that do not borrow, such as Icelandic or Chinese, the trick is to nevertheless use one-to-one relationships with the international Begriffsgemeinschaft.

\$5 The sample used in this chapter is admittedly small, but nonetheless it is hoped that it can illustrate some interesting trends. The path of least resistance for a language is certainly to take on scientific terms as loanwords, possibly adapting their phonetics slightly. English or Russian do this often in the above sample, but it can be done in much more extreme ways, as for instance Indonesian does. It takes on scientific words very widely, from whatever source lies at hand (gravitasi, oksigen, predikat, ablaut, vokal, ...). The disadvantage of this approach is, of course, that the new words are not integrated into the language, their structure is not immediately clear to speakers, and they cannot easily be further modified, so they tend to remain erratic blocks in the fabric of the language in question. In this respect, it would seem to be a much better strategy to make calques (as Icelandic and Modern Greek often do), or even to build the concepts from existing ones, independently of how this was done in the source language, as Chinese usually does. A good example is 乙酸 y̌suān ('second acid'), ${ }^{35}$ which is much more logical than our historically evolved 'acetic acid'. The disadvantage in this is the enormous effort the linguistic community has to undertake to enable it, and indeed this approach seems to be rare among languages. German is an example of a language that uses both strategies, sometimes even for one and the same concept (Gravitation vs Schwerkraft, etc.). But it seems that German has done this in a much less confident manner since the two lost World Wars, especially in the natural sciences, in the case of which German seems to have resigned itself to being replaced by English.

Comparing the two sample sciences, striking general differences can be observed: whereas the chemistry vocabulary comes by and large from Latin (sometimes through French or English), that of linguistics tends to stem from Greek or German. The former science is also much more global: the two non-European and non-Indo-European languages Arabic and Chinese have developed clearly visible strategies for incorporating chemical terminology from European chemistry; this is much less the case in linguistics. In contrast, Icelandic has a harder time with the chemical terminology than the linguistic one. The latter is based on Greek or

35 i.e. the organic acid with two carbon atoms. 
German compounds which Icelandic can very easily reproduce. The only case that might not be one-to-one is the Icelandic hljóðskipti, literally 'sound shift' but apparently used for the different concept 'ablaut'. Chemistry, especially due to the enormous size of its vocabulary (e.g. the many compounds in organic chemistry), made Icelandic unfaithful to its philosophy of not taking over foreign words: nikkel and glúkósi are still relatively harmless cases. 'DNA' is only translated halfway, as deoxý-ríbósa-kjarn-sýra, which is, however, still usually addressed in its abbreviated English form as DNA. ${ }^{36}$

The historical development of languages into carriers of European science has not yet been studied comparatively. Although in the nineteenth century many smaller European languages started to acquire their scientific vocabulary, they have on the whole not been able to produce important publications for the simple reason that the leading scientists cannot be expected to read more than three or four languages. After a fight for scientific hegemony among Italian, French, German, and English, and quite soon only the latter three, this struggle, which forced scientists to learn more languages than during times of Latin hegemony, when one was enough, seems to be coming to a temporary halt now, with English emerging as "winner'. ${ }^{37}$ Most natural sciences publish serious contributions only in English now. In Classics and in Mediaeval Latin studies, we are still in the comfortable situation that all of the four mentioned languages are equally acceptable for important publications, although there does seem to be a growing tendency for native speakers of English to stop reading publications in other languages, a fact that may ultimately force the others to switch to English as well.

Despite this tendency toward monolingualism in science, all languages used at least as the official language of a state or region, thus for instance in schools and administration, have had to learn to express the fast-growing international scientific terminology. The strategies have depended on the language: smaller Indo-European languages have followed their closest 'major' relatives; nonIndo-European languages with large resources and a strong sense of their own culture will do something similar to what we have seen the Chinese do; those that do not (the majority) will more likely follow an Indonesian strategy. It would certainly be interesting to study this in further languages, but this is clearly outside the scope of the present study concerned with Latin.

36 As at https://is.wikipedia.org/wiki/DNA.

37 This book is an example of this: half a century ago, I would certainly have written it in German, two centuries ago in Latin. 


\section{Developments in the twenty-first century}

\$6 In some fields, new coinings are still expected to have a fully Greek or Latin name in the twenty-first century. Above (chap. 15 §5), botany was briefly discussed in this respect. In astronomy newly discovered features, for instance on the former planet Pluto, still receive Latin names, such as Cthulhu regio, Hillyra montes (discovered by NASA in 2015). More frequently, it is still the rule to form new scientific words from Greek and Latin components, especially in English, which is so deeply rooted in Latin and French that Latin coinings come very naturally to speakers. A similar phenomenon was described by Henry Bradley for English in general - that 'the whole Latin vocabulary' had become 'potentially English' (1904: 94-95):

\footnotetext{
It has come to be felt that the whole Latin vocabulary, or at least that portion of it which is represented in familiar classical passages, is potentially English, and when a new word is wanted it is often easier, and more in accordance with our literary habits, to anglicize a Latin word, or to form a compound from Latin elements, than to invent a native English compound or derivative which will answer the purpose.
}

From English these new terms tend to move to other languages, nowadays sometimes even into Chinese. For instance, fullerenes - a recently discovered form of carbon that is named after Richard Buckminster Fuller and thus does not bear a Graeco-Latin name - are called 富勒烯 fù lè xì, where 烯 $x \bar{l}$ means 'alkene' and thus describes the fact that there are double bonds in fullerenes, but the first two characters are phonetic. Thus, something like a scientific koine based mostly on Latin and Greek constituents comes into existence, from which scientific English terms can be appropriated easily by most other languages.

A similar trend existed among Latin humanists, who incorporated Greek terms and phrases into their writings very frequently and usually without any explanation. Within Europe, an unusual intellectual cohesion, largely thanks to the classical languages, can be observed: besides the mentioned related languages (Romance, Germanic), later additions such as Slavonic and unrelated languages such as Hungarian, Finnish, or Basque have also shared in this largely similar intellectual milieu or Begriffsgemeinschaft; only the comparison with distant nonEuropean languages such as Arabic and Chinese makes clear that this milieu is by no means a matter of course, although the past century with its overwhelming success of European science largely brought such other language communities into a situation in which they could no longer ignore it. Quite in general, much in our modern languages is built out of jetsam and flotsam from Latin and Greek, which has often changed its meaning decidedly and is usually used unconsciously by speakers. Often the constituent parts become hardly recognisable, as some random examples from vehicle names show: 'tandem bike' with no obvious 
relation to the Latin particle tandem; the French automobile (from questionable Neo-Latin automobilis) turning into German Auto, but Swedish bil; or the case ending of omnibus turning into 'bus'.

Despite this, over the past few centuries a mostly one-to-one correspondence for scientific terms among all major languages has evolved. This is the deeper reason for the easy translatability postulated by some scholars and mentioned earlier (chap. 16 §4). Scientific terms thus largely function like proper names, even those that are not nouns (verbs may be avoided in translation, as German ablauten, English 'undergo ablaut' indicates). In other language domains, this is not at all the case. Examples of words that cannot be translated between pairs of languages without lengthy explanations abound. A few that can be mentioned for the closely related languages German and English are Fingerspitzengefühl, gönnen, or artgerechte Tierhaltung, and 'obnoxious', 'posh', or 'mind'. This finding indicates that the success of modern science in everyday life led to a claim to international and intercultural validity, thus to being, as much as possible, independent of the quirks of individual languages. But in reality the contemporary language of science is very strongly based on Greek, Latin, English, and possibly some other European languages, and on our European Begriffsgemeinschaft. The modern scientific way of thinking is still today decidedly Graeco-Latin. 